\title{
Морфологічні особливості репаративного процесу в зоні трофічних венозних виразок нижніх кінцівок за умов застосування аутоплазми, збагаченої тромбоцитами
}

\author{
І. Д. Дужий, В. М. Попадинець, А. М. Романюк, А. С. Ніколаєнко, О. В. Кравець,
} В. В. Сікора, М. С. Линдін

Сумський державний університет

\section{Morphological features of reparative process in trophic venous lower-extremity ulcers using autologous platelet-rich plasma}

\author{
I. D. Duzhiy, V. M. Popadynets, A. M. Romaniuk, A. S. Nikolaienko, O. V. Kravets, \\ V. V. Sikora, M. S. Lyndin \\ Sumy State University
}

\begin{abstract}
Реферат
Мета. Дослідити стан регенерації тканин у зоні трофічних виразок венозного генезу.

Матеріали і методи. Протягом 2017 р. на базі хірургічного відділення Сумського обласного клінічного госпіталю ветеранів війни проведено лікування 57 хворих з трофічними виразками нижніх кінцівок шляхом застосування аутоплазми, збагаченої тромбоцитами (АПЗТ).

Результати. На 20-ту добу від початку лікування у хворих основної групи площа виразкового дефекту зменшувалась на 45,8\% у порівнянні з вихідними даними, у хворих контрольної групи - лише на 31,4\%, що в 1,4 разу менше (р <0,05).

Висновки. Покращення регенерації тканин у зоні виразки за рахунок епідермізації скорочує строки їі епітелізації у разі застосування АПЗТ у 2,3 разу.

Ключові слова: трофічна виразка; хронічна венозна недостатність; аутоплазма, збагачена тромбоцитами; подопланін; СД31.

Abstract

Objective. Aim to study process of tissue reparation in zone of trophic ulcers of venous origin

Materials and methods. A total of 57 patients with lower-extremity trophic ulcers was included during their treatment using autologous platelet-rich plasma at the Department of Surgery of Sumy Hospital for Military Veterans of Second World War. Results. On day 20, the main group had decrease of ulcer defect in $45.8 \%$ out of the initial surface. In group of comparison this measurement was 31.4\%, 1.4-fold less than in the main one.

Conclusions. Using autologous platelet-rich plasma advances regeneration in zone of ulcer and shortens the period of epithelium formation in 2.3 -fold.

Keywords. trophic ulcer, chronic venous insufficiency, autologous platelet-rich plasma, podoplanin, CD 31.
\end{abstract}

За даними ВООЗ, на хронічну венозну недостатність (ХВН) хворіють 15 - 50\% дорослого населення у всьому світі [1, 2], а найтяжчим ускладненням ХВН є трофічні виразки (ТВ). Венозні ТВ, які фіксують у 0,1 - 1,5\% всього населення Земної кулі $[3,4]$, за даними різних авторів, становлять близько 75\% усіх виразок нижніх кінцівок (НК) [5]. У людей старшого і похилого віку їх частота зростає у більш як 3 рази, що призводить до значних фінансових витрат на лікування даної патології. У розвинених країнах такі витрати фінансують у розмірі 1 - 2\% бюджетних витрат на медичне обслуговування [6, 7]. Вони додатково зростають у разі повторних звернень та госпіталізаціі хворих з рецидивуючими ТВ, частота виникнення яких протягом першого року після загоєння становить 60\% [8].

Наведене підтверджує, що проблема лікування венозних ТВ залишається актуальною, а іiі розв'язання потребує новітнього комплексного підходу та застосування сучасних технологій, які б стимулювали процеси репарації у виразкових тканинах.

В останні роки з'явилися повідомлення щодо активації метаболічних і репаративних процесів у рані у разі за- стосування аутоплазми, збагаченої тромбоцитами (АПЗТ - platelet-rich plasma) [9, 10], яка містить значну кількість факторів росту, а саме: тромбоцитарний фактор росту - Platelet Derived Growth Factor (PDGF), трансформуючий фактор росту бета - Transforming Growth Factor Beta (TGF $\beta$ ), епідермальний фактор росту - Epidermal Growth Factor (EGF), судинний ендотеліальний фактор росту Vascular Endothelial Growth Factor (VEGF), інсуліноподібний фактор росту 1 - Insulin Like Growth Factor 1 (IGF-1), фібробластичний фактор росту - Fibroblast Growth Factor (FGF) тощо [11]. В експерименті встановлено, що тромбоцити разом із зазначеними біологічно активними речовинами здатні впливати на нейтрофіли та стимулювати їх антимікробні, протизапальні та регенераційні властивості [12]. Більше того, деякі вчені вважають, що плазма, збагачена тромбоцитами, є надійним замінником стовбурових клітин [13]

Процес регенерації тканин у зоні хронічної венозної TВ є багатокомпонентним і складним, у ньому бере участь значна кількість клітин і сполук. Поміж останніх важливу роль у патогенетичному розумінні відіграють молекули 
адгезії тромбоцитарно-ендотеліальних клітин (CD31) та білок подопланін. У процесі регенерації виразкового дефекту наявність експресії рецепторів до CD31 дає можливість уточнити рівень адекватної васкуляризації та іiі вплив на загоєння виразкової рани $[14,15]$. Білок подопланін вважають специфічним маркером, виявленим в ендотеліоцитах лімфатичних судин у процесі регенерації [16]. На думку R. Mani і співавторів, подопланін свідчить про існування компенсаторного лімфоангіогенезу (кількість виявлених лімфатичних судин на одиницю виміру) [17]. VEGF - білок, який секретують клітини в процесі стимуляції васкуло- й ангіогенезу, відновлюючи подачу кисню до гіпоксично уражених тканин у разі циркуляторної недостатності [18].

3 огляду на актуальність проблеми поліпшення результатів лікування виразкової хвороби НК та дані щодо наявності факторів росту в тромбоцитах, які можуть стимулювати процеси регенерації тканин, вивчення їх впливу на заживлення ТВ є вельми своєчасним.

Мета дослідження: вивчити стан регенерації тканин у зоні ТВ венозного характеру і дослідити вплив на нього АПЗТ шляхом проведення гістологічних та гістохімічних досліджень.

\section{Матеріали і методи дослідження}

Протягом 2017 р. на базі хірургічного відділення Сумського обласного клінічного госпіталю для ветеранів війни проведено лікування 57 хворих з ТВ НК із застосуванням АПЗТ (основна група). Чоловіків було 18 (31,6\%), жінок - 39 (68,4\%). Середній вік чоловіків становив 70 років, жінок - 65 років. Від моменту появи ТВ на тлі ХВН до початку лікування у чоловіків минуло 5,2 року, у жінок 7,3 року.

У 45 (78,9\%) хворих ТВ виникли внаслідок первинного варикозного розширення вен НК, у 12 (21,1\%) - посттромбофлебітичного синдрому.

Критеріями включення хворих у дослідження були: площа виразки до 10 см², стадія C4-С6 за міжнародною класифікацією хронічних захворювань вен (СЕАР). Хворі надали письмову згоду на застосування у процесі лікування АПЗТ. Критерії невключення хворих у дослідження: старече виснаження, хвороба Альцгеймера, кровотеча.

У хворих основної групи в процесі лікування використовували власну плазму крові, збагачену тромбоцитами, яку отримували шляхом дворазового центрифугування у режимі 1500 і 1700 обертів за 1 хв, після чого активували 10\% розчином хлористого кальцію.

Алгоритм лікування. Спочатку виконували оперативне втручання за типом некректомії виразки. На наступну добу в зону порушеної трофіки з трьох точок на відстані 1 см від межі виразки під кутом 45 вводили АПЗТ у кількості 1,5 мл. АПЗТ вводили двічі з інтервалом 10 днів. Доповнювали дане лікування місцевими аплікаціями АПЗТ, укладаючи «тромбоцитарний» згусток на виразковий дефект. Перев'язки виконували з інтервалом 2 дні.

Контрольну групу склали 20 хворих з ТВ такою ж площею, що і в основній групі. Цих хворих лікували згідно з регіонарними протоколами, в основу яких покладена стандартна медикаментозна терапія та місцеве застосу- вання мазей левомеколь, левосин. Хворим обох груп проводили ультразвукове дослідження венозного відтоку від НК, вивчали мікробіоценоз виразок, лабораторні показники крові.

Клінічну ефективність лікування оцінювали на 10, 20 ту та 30-ту добу від його початку, враховуючи наявність больового синдрому, зменшення набряку, появу грануляцій. Виписували хворих з клініки тоді, коли констатували повне очищення виразки та появу крайової епітелізації.

Матеріал для гістологічного і імуногістохімічного (IГХ) досліджень забирали на межі здорової і виразкової ділянок під місцевою анестезією на 20-ту добу від початку лікування.

Гістологічно біопсійний матеріал досліджували, використовуючи депарафіновані зрізи тканини завтовшки 7 мкм після забарвлення їх гематоксиліном та еозином. Критеріями репаративного процесу, досліджуваного за допомогою світлооптичної мікроскопії, були: швидкість епідермізації, васкуляризації, елімінації деструктивних утворень та зменшення інтенсивності запальної інфільтрації. Площу виразкового дефекту розраховували методом Kundin [19].

Основну увагу приділяли якісним та кількісним характеристикам стану ангіогенезу, для цього проводили IГХ дослідження рецепторів до CD31, подопланіну та VEGF.

Зрізи завтовшки 5 мкм депарафінували за стандартною методикою, зневоднювали у ксилолі та спиртах зростаючої концентрації. Демаскування антигенів здійснювали у водяній бані «ВБ-4» за температури $97-98^{\circ} \mathrm{C}$. Реакцію антиген-антитіло візуалізували з використанням системи детекціï «Ultra Vision Quanto Detection System HRP DAB Chromogen» («Thermo scientific», США).

Для аналізу результатів проведених досліджень та підтвердження їх вірогідності застосовували методи варіаційної статистики (критерій Ст'юдента).

\section{Результати}

На 10-ту добу спостереження у хворих основної групи суттєво зменшились больові відчуття, набряк тканин у зоні виразкового дефекту та навколо нього практично зник, чого не спостерігали у хворих контрольної групи. Даний ефект могли зумовити покращення венозного відтоку та відновлення лімфатичної дренажної системи.

За рахунок росту грануляцій та епітелізації ТВ на 20ту добу від початку лікування у хворих основної групи виразковий дефект зменшився на 45,8\% у порівнянні з вихідними даними, у контрольній групі - на 31,4\%. Оскільки показник епітелізації ТВ був обраний як орієнтир щодо можливої виписки хворих із стаціонару, хворих основної групи виписували із стаціонару через 15,1 доби, контрольної - через 23,4 доби ( $<$ 0,05). Середній строк епітелізації виразкового дефекту у хворих основної групи становив 35,8 доби (від 33 до 38 діб), контрольної - 83,2 доби (від 80 до 89 діб).

\section{Обговорення}

Достовірне зменшення розмірів виразкового дефекту у хворих основної групи порівняно з хворими контрольної групи було більшим у 1,4 разу ( $<$ 0,05) та розпочинало- 


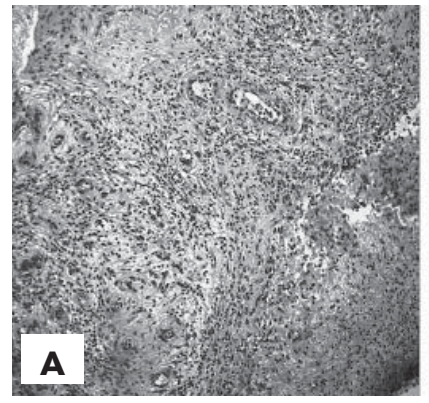

Puc.1.
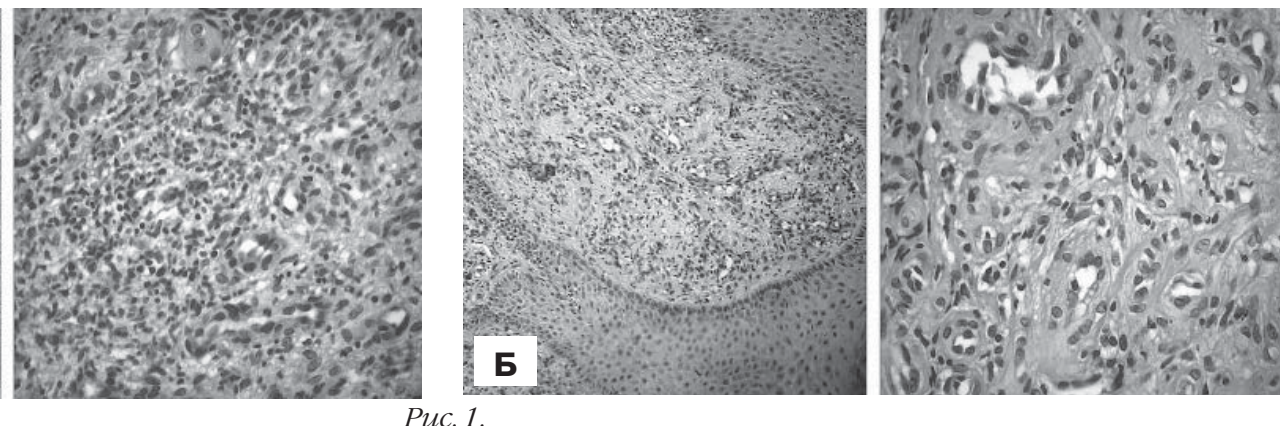

(Б) групи на 20-mу добу. Забарвлення гематоксиліном та еозином. Зб. ×100, ×400.
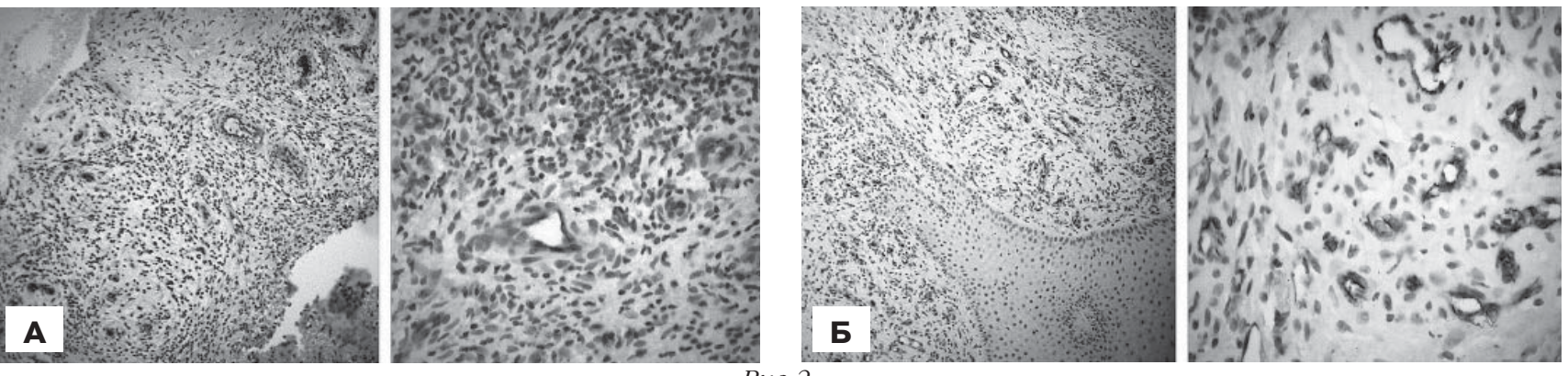

Puc.2.

Фрагмент виразкового дефекту шкіри гомілки хворих контрольної (А) та основної (Б) групи на 20-mу добу Імуногістохімічне дослідження рещепторів до CD31.

Забарвлення гематоксиліном та еозином. $6 б . \times 100, \times 400$.
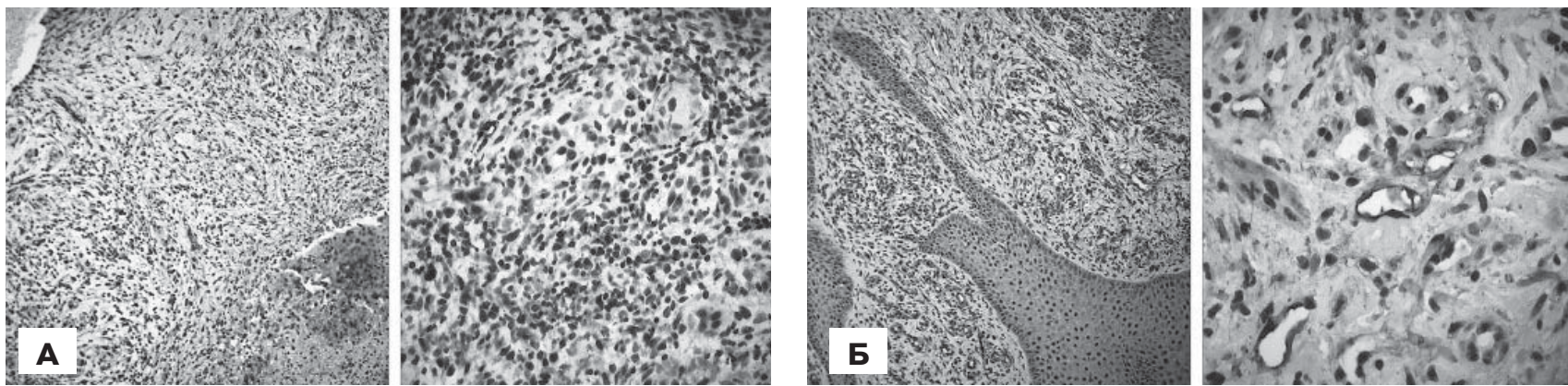

Puc.3.

Фрагмент виразкового дефекту шкіри гомілки хворих контрольної (А) та основної (Б) групи на 20-ту добу. цмуногістохімічне дослідження рецепторів до подопланіну. $36 . \times 100, \times 400$.
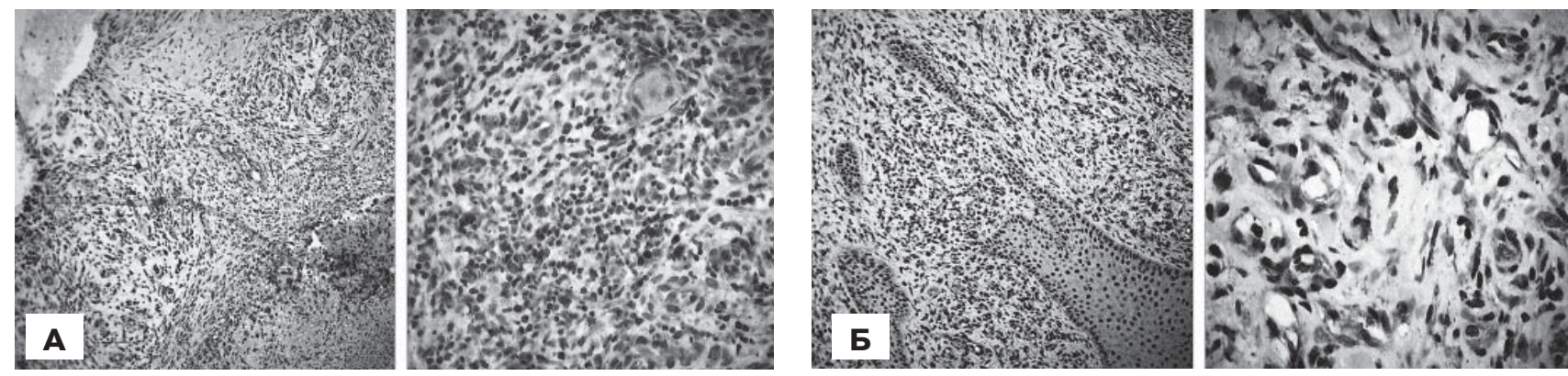

Puc. 4 .

Фрагмент виразкового дефекту шкіри гомілки хворих контрольної (А) та основної (Б) групи на 20-ту добу.

Lмуногістохімічне дослідження рещепторів до VEGF.3б. ×100, ×400.

ся з периферії виразки, тобто із зони, у яку вводили АПЗТ, що свідчило про стимуляцію камбіальних клітин у цій зоні факторами росту, які містяться в АПЗТ, та їх проліферацію. Виявлений інтенсивний ріст рецепторів до CD31, VEGF та подопланіну у хворих основної групи, стимульований АПЗТ, підтверджує наявність у цій фракції плазми факторів росту.
Гістологічним дослідженням біоптатів, взятих на межі здорової тканини і виразки, у хворих контрольної групи виявлено інтенсивну запальну інфільтрацію змішаного клітинного характеру (нейтрофіли, еозинофіли, лімфоцити, макрофаги), яка найчастіше локалізувалась навколо залишків некротизованої тканини. Епідермізація поширю- 
валася з периферійних ділянок та супроводжувалася субепітеліальною запальною інфільтрацією з наявністю незрілої грануляційної тканини. Поміж грануляційних утворень визначалися поодинокі судини. У біоптатах хворих основної групи спостерігали повну елімінацію деструктивних тканин, відсутність запальної інфільтрації та чітко виражену васкуляризацію, представлену артеріолами, капілярами, тонкостінними венулами та лімфатичними судинами. Епідермізація сягала центральних ділянок виразкового дефекту на тлі зрілої грануляційної тканини (рuс. 1).

За даними ІГХ дослідження біоптатів хворих основної групи встановлено значно більшу кількість різнокаліберних судин (капілярів, венул та артеріол), які значно щільніше розташовувались у зоні грануляційної тканини, проте їх було відносно менше у прилеглих ділянках і в центральній зоні виразки. Про інтенсивність васкуляризації свідчила наявність рецепторів до CD31-позитивних структур. У хворих контрольної групи наявність таких рецепторів та інтенсивність ангіогенезу були значно меншими (рис. 2).

Однією з основних характеристик репаративного процесу є рівень відновлення лімфатичної дренажної системи. Досліджуючи експресію рецепторів до подопланіну у хворих обох груп, ми виявили наявність позитивних структур у складі біопсійного матеріалу: стромальних клітин, поодиноких клітин запального інфільтрату та ендотеліоцитів лімфатичних судин. Підрахунок кількості подопланін-позитивних компартментів показав достовірну більшу наявність лімфатичних судин у хворих основної групи (рис. 3).

Індикатором ендогенного ангіогенного потенціалу регенеруючої тканини стало ІГХ дослідження рецепторів до VEGF. У біопсійному матеріалі виявлено мозаїчне розташування діамінобензидин-позитивних структур: клітин сполучної тканини, імуноцитів, ендотелію судин. Порівняльний аналіз наявності VEGF-позитивних структур (стромальної та ендотеліальної фракції цих молекул) показав, що у біоптатах хворих основної групи вона більша (рис. 4).

Наведені зміни підтверджують ангіогенний потенціал АПЗТ, який реалізується в індукції синтезу VEGF, що збільшує кровонаповнення гіпоксично ураженої тканини за рахунок утворення кровоносних судин та виведення накопичених залишків метаболізму через утворені венозні та лімфатичні судини. У кінцевому підсумку відбувається інтенсифікація регенерації виразкового дефекту, прискорене його заживлення, що приводить до скорочення строків стаціонарного лікування, зменшення фінансових витрат та покращення якості життя хворих.

\section{Висновки}

1. АПЗТ стимулює концентрацію факторів росту в ділянці виразкового дефекту, що підтверджується значним накопиченням рецепторів до CD31, VEGF та подопланіну.

2. Синтез VEGF сприяє ангіогенезу в зоні TB, що стимулює процеси репараціі.

3. Збільшуючи рівень експресії рецепторів до подопланіну, АПЗТ стимулює утворення лімфатичних судин, що сприяє виведенню продуктів метаболізму, зменшен- ню набряку в зоні виразки та інтенсифікації регенеративних процесів.

4. Покращення регенерації в зоні ТВ за рахунок епідермізації скорочує термін епітелізації ТВ у разі застосування АПЗТ у 2,3 разу $(\mathrm{p}<0,05)$.

5. Враховуючи, що АПЗТ впливає на накопичення в зоні виразки факторів росту, доцільно вивчити даний феномен у хворих з виразками та ранами іншого генезу, що розширить уявлення про патогенез виразкової та ранової хвороби.

\section{References}

1. Burleva EP, Fokin AA, Ermolaev VL, Ivanov EV. Vvedenie v angiologiju i sosudistuju hirurgiju. Ekaterinburg: Basko; 2015. 306 s. [In Russian].

2. Pokrovskij AV, Gradusov EG, Ignat'ev IM, Bredihin RA. Diagnostika i lechenie posttromboticheskoj bolezni : uchebnoe posobie: Moskva; 2011. 94 s. [In Russian].

3. Rabe E, Pannier F. Societal costs of chronic venous disease in CEAP C4, C5, C6 disease. Phlebology. 2010 Oct;25 Suppl 1:64-7. doi: 10.1258/ phleb.2010.010s09.

4. Abbade LPF, Lastoria S. Venous ulcer: epidemiology, physiopathology, diagnosis and treatment. International Journal of Dermatology. 2005;44(6):449-56. doi: 10.1111/j.1365-4632.2004.02456.x

5. Popadiuk BP. Konservatyvne likuvannia khvorykh litnoho ta starechoho viku na trofichni vyrazky nyzhnikh kintsivok v umovakh ambulatorii zahalnoi praktyky i simeinoi medytsyny. Bukovynskyi medychnyi visnyk. 2017;21(3):169-74. [In Ukrainian].

6. Rusyn VI, Levchak YuA, Rusyn AV. Khirurhichne likuvannia khronichnoi venoznoi nedostatnosti. Klin khir. 2003 Grud;(12):21-3. [In Ukrainian].

7. Abbade LPF, Lastória S, de Almeida Rollo H. Venous ulcer: clinical characteristics and risk factors. Int J Dermatol. 2011 Mar;50(4):405-11. doi. org/10.1111/j.1365-4632.2010.04654.x.

8. Eberhardt RT, Raffetto JD. Chronic Venous Insufficiency. Circulation. 2014 Jul 22;130(4):333-46. doi.org/10.1161/CIRCULATIONAHA.113.006898.

9. Bogdan VG, Tolstov DA. The platelet concentrates use in trophic ulcers treatment. Novosti hirurgiyi. 2014;22(3):344-50. [In Russian].

10. Duzhiy I, Popadynets V, Nikolaienko A, Lyndin M, Sikora V. Hypertensive ulcer of lower extremity (Martorell's syndrome): clinical case with the treatment. Bangladesh Journal of Medical Science. 2017;16(02):32528. http://dx.doi.org/10.3329/bjms.v16i2.31212.

11. Achkasov EE, Bezuglov JeN, Ul'janov AA, Kurshev VV, Repetjuk AD, Egorova ON. Primenenie autoplazmy, obogashhennoj trombocitami, v klinicheskoj praktike. Biomedika. 2013;(3):46-59. [In Russian].

12. Szponder T, Wessely-Szponder J, Smolira A. Evaluation of PlateletRich Plasma and Neutrophil Antimicrobial Extract as Two Autologous Blood-Derived agents. Tissue Eng Regen Med. 2017 Jun;14(3):28796. doi.org/10.1007/s13770-017-0035-4.

13. Chouw A. Proliferation and characterization of Wharton-jelly's derived mesenchymal stromal cell using plasma rich platelet and plasma platelet lysate.Cytotherapy. 2017 May; 19(5): 152. doi.org/10.1016/j. jcyt.2017.02.230.

14. Newman PJ. The biology of PECAM-1. J Clin Invest. 1997 Jan 1;99(1):3-8. doi:10.1172/JCI119129.

15. Agarwal S, Loder S, Cholok D, Peterson J, Li J, Fireman D, et al. Local and circulating endothelial cells undergo endothelial to mesenchymal transition (EndMT) in response to musculoskeletal injury. Sci Rep. 2016;6:32514. doi: 10.1038/srep32514.

16. Astarita JL, Acton SE, Turley SJ. Podoplanin: emerging functions in development, the immune system, and cancer. Front Immunol. $2012 \mathrm{Sep}$ 12;3:283. doi:10.3389/fimmu.2012.00283.

17. Mani R, Romanelli M, Shukla V. Measurements in wound healing. science and practice. Springer-Verlag London; 2013.398 p.

18. Ferrara N, Gerber HP, LeCouter J. The biology of VEGF and its receptors. Nat Med. 2003 Jun;9(6):669-76. doi:10.1038/nm0603-669.

19. Savchenko JuP, Fedosov SR. Metody opredelenija ranevoj poverhnosti. Vestn. hirurgii im. Grekova. 2007;166(1):102-5. [In Russian]. 